\title{
Effect of vitamin E addition to frozen Simmental bull semen extender on post-thawing quality
}

\author{
Fariz Zharfan Haris ${ }^{1 *}$, Yon Soepri Ondho ${ }^{2}$, and Daud Samsudewa ${ }^{3}$ \\ ${ }^{1}$ Faculty of Animal and Agricultural Science, Diponegoro University
}

\begin{abstract}
The purpose of this research was to evaluate the post-thawing quality (sperm motility, mortality and abnormality) of frozen-thawed Simmental bull semen with the addition of vitamin $E$ in the extender. The material used for research were semen from two selected Simmental bulls. Vitamin $E$ as treatment in addition to the extender consisted of T0 (no addition of vitamin E), T1 $(0,134 \mathrm{gram} / 100 \mathrm{ml}$ extender), T2 $(0,268$ gram $/ 100 \mathrm{ml}$ extender) and T3 $(0,402 \mathrm{gram} / 100 \mathrm{ml}$ extender). Post-thawing evaluation conducted 24 hours after the freezing process and observed after the thawing process in $37^{\circ} \mathrm{C}$ water bath for 30 seconds. Parameters observed in this research were the post-thawing quality of frozen-thawed Simmental bull semen based on motility, mortality and abnormality percentage. Sperm motility evaluated using a microscope with $100 x$ and 400x magnifying, sperm mortality observed using 400x magnifying and counted based on $0,2 \%$ eosin-negrosin staining, sperm abnormality observed using 400x magnifying and counted based on the number of morphologically abnormal sperm cells. Semen post-thawing motility was not significantly affected by vitamin $\mathrm{E}$ addition of $\mathrm{T} 1, \mathrm{~T} 2$ and $\mathrm{T} 3(\mathrm{P}<0,05)$. T1 and $\mathrm{T} 2$ were able to significantly lower the mortality percentage compared to T0 and T3 $(\mathrm{P}<0,05)$. T1 and T2 were also very significantly affecting the decreased of abnormality percentage compared to T0 and T3 $(\mathrm{P}<0,01)$. T1 generally gave the best result on the improvement of post-thawing motility and decreased the percentage of sperm mortality and abnormality.
\end{abstract}

\section{INTRODUCTION}

Artificial insemination center has been established on several provinces in Indonesia in order to fulfill the necessity of frozen semen for artificial insemination process. Artificial insemination in Indonesia mostly applied to bovines and goats. Artificial insemination was also one of the main government programs to increase the population of beef cattle nationally. Frozen semen quality is one of many indicators that affect the success rate of artificial insemination. Several factors that could determine the quality of frozen semen are the genetic quality of bull, semen production process and implementation of artificial insemination [1]. Simmental bull semen was one of the most used kinds of semen by some inseminators in Indonesia.

Frozen semen production consisted of a series of the process including semen dilution in extender, freezing, cold storage and post-thawing evaluation. During cooling and freezing process, sperm cells are susceptible to get the harmful effect from unbalanced osmotic pressure, protein denaturation, cellular acidosis, energy loss, membrane breakdown, crystallization of cells body, destabilization of the cytoskeleton and formation of free radicals or reactive oxygen species (ROS) [2].

Vitamin $\mathrm{E}$ is an antioxidant act as beneficial molecules on sperm cells by neutralizing $\mathrm{H}_{2} \mathrm{O}_{2}$ and inhibiting reaction with free radicals. Vitamin $\mathrm{E}$ can break the chain reactions and protecting the membrane from the damage caused by ROS [3]. Vitamin E as an antioxidant also can prevent lipid peroxidation. Lipid peroxidation on spermatozoa will result in the loss of motility, decrease in cell fructolysis and respiration activity and leakage of cell fluid through damaged membrane. Antioxidants such as vitamin E are known for their ability to give protection to the sperm membrane by inhibiting the formation of ROS and lipid peroxidation [2].

The main purpose of this research was to evaluate the post-thawing quality (sperm motility, mortality, and abnormality) of frozen-thawed Simmental bull semen with the addition of vitamin $\mathrm{E}$ in the extender. This research might have the benefit of increasing the postthawing quality of Simmental bull semen after the addition of vitamin $E$ in semen extender and resulting in the increase of frozen semen production at the artificial insemination center.

\section{MATERIALS AND METHODS}

This research had been conducted on September to November 2018 at Artificial Insemination Center Ungaran, Sidomulyo District Complex, Semarang Regency. The main material used for research was semen from two selected Simmental bull samples which can produce semen with consistent quality during standard collection. Semen collected twice a week using standard procedures. Other materials used for semen processing were vitamin $\mathrm{E}$, eosin-negrosin $0,2 \%$, aqua dest, glycerol 96\%, market free penicillin and streptomycin antibiotics, egg yolk - skim extender and liquid nitrogen. Apparatus used for semen processing and observation were pipette, hand counter, microscope, measuring cup, beaker glass, stirrer, object-glass, thermometer, cooling top, mini straw, freezing machine dan filling-sealing machine. 


\subsection{Experimental Design}

The experimental design used for this research was completed randomized experimental design with 4 treatments and 6 repetitions. Treatments for this research consisted of :

T0 : no addition of vitamin $\mathrm{E}$

T1 : 0,134 gram $/ 100 \mathrm{ml}$ extender

T2 : $0,268 \mathrm{gram} / 100 \mathrm{ml}$ extender

T3 : 0,402 gram / $100 \mathrm{ml}$ extender

Parameters observed in this research were the postthawing quality of frozen-thawed Simmental bull semen based on motility, mortality and abnormality percentage.

\subsection{Procedures}

The research procedures consisted of semen preparation, treatment process, fresh semen evaluation, post-thawing motility observation, mortality observation, and abnormality observation

\subsubsection{Semen preparation}

The preparation process started with making semen extender. The extender used for Simmental bull semen was egg yolk and milk mixtures as a stock solution. Initially, the extender divided into extender $\mathrm{A}$ and extender B consisting volume of $100 \mathrm{ml}$ for each extender. Extender A consisted of $10 \mathrm{~g}$ of skim powder, aquadest, $10 \%$ of egg yolk, $1 \%$ of glucose and $1 \%$ of penicillin and streptomycin antibiotics. Extender B divided into 4 kinds from each of treatments, each of them consisted of 10 gram of skim powder, aquadest, $10 \%$ of egg yolk, $1 \%$ of glucose, $16 \%$ of glycerol, $1 \%$ of penicillin and streptomycin antibiotics and vitamin $\mathrm{E}$. Total volume of extender can be calculated by the following formula [4] :

$$
\text { Total Extender Volume }=\frac{V \times M \times K}{100 \times 10^{8}}-V
$$

$V:$ Semen volume $(\mathrm{ml})$

$M$ : Semen motility (\%)

$K:$ Semen concentration

\subsubsection{Treatment process}

Semen collected from the bull in the cylinder tube placed in a water bath with $37^{\circ} \mathrm{C}$ temperature. The semen then evaluated macroscopically based on volume, color, consistency, odor, $\mathrm{pH}$ and microscopically based on mass motility, individual motility and concentration. Semen volume needed to make 4 straw of frozen semen for each treatment was $0,3 \mathrm{ml}$. Semen mixed with extender A then temporarily stored in the cool top with $5^{\circ} \mathrm{C}$ temperature. Extender $\mathrm{B}$ added into the mixture of extender $\mathrm{A}$ and semen 50 minutes later then stored again in the cool top for the equilibration process for 3 hours. After the equilibration process, the semen extender mixture went into the filling and sealing machine to be stored in mini straw, then into freezing machine. Postthawing evaluation conducted 24 hours after the freezing process and observed after thawing process in $37^{\circ} \mathrm{C}$ water bath for 30 seconds.

\subsubsection{Fresh semen evaluation}

Fresh semen collected from selected Simmental bulls twice a week. Semen evaluated macroscopically based on volume, color, odor, $\mathrm{pH}$, consistency and microscopically based on mass motility, individual motility, and sperm concentration.

\subsubsection{Post-thawing semen motility observation}

Post-thawing motility of semen observed just before distribution as a part of the quality control procedure. Frozen semen which was taken from liquid nitrogen storage has to be thawed in water bath with $37^{\circ} \mathrm{C}$ temperature for 30 seconds. Semen will then be evaluated using a microscope with 100x and 400x magnifying to observe individual spermatozoa motil movement. Sperm cell which was categorized as motil would has quick and straight movement. Observation performed in five different fields of view and then counted the average percentage.

\subsubsection{Semen mortality observation}

Mortality percentage counted by observing semen sample which has been stained by coloring reagent of eosin-negrosin $0,2 \%$ using a microscope with $400 \mathrm{x}$ magnifying. Observation conducted on five different fields of view with total spermatozoa counted must be greater than or equal to 200 cells. Mortal spermatozoa cell would be seen in dark purple or red color during observation. It was because mortal spermatozoa indicated that its membrane did not function properly as normal to filtrate some of the harmful substances.

\subsubsection{Semen abnormality observation}

Semen abnormality observation performed using a microscope with 400x magnifying on five fields of view. Total spermatozoa counted must be greater than or equal to 200 cells.

\section{RESULTS AND DISCUSSIONS}

\subsection{Fresh Semen Evaluation}

Fresh semen collected from Simmental bull temporarily stored in sperm vial to be transported to labortory for evalution process. Result of Simmental bull fresh semen evaluation is shown on Table 1 . 
Table 1. Observation result of Simmental bull fresh semen evaluation

\begin{tabular}{cc}
\hline Quality Parameter & Result \\
\hline Volume $(\mathrm{ml})$ & $6,90 \pm 0,91$ \\
Color & Cream \\
Consistency & Medium \\
Odor & Spermin \\
pH & $6,43 \pm 0,20$ \\
Mass motility & +++ \\
Concentration $\left(10^{6}\right.$ sperm $\left./ \mathrm{ml}\right)$ & $1.864 \pm 170,56$ \\
Individual motility $(\%)$ & $73,01 \pm 1,78$ \\
\hline
\end{tabular}

Result on Table 1. showed that Simmental bull fresh semen had 6,90 $\pm 0,91 \mathrm{ml}$ volume, cream color, medium consistency, spermin odor, $\mathrm{pH} 6,43 \pm 0,20$, mass motility +++ and $1.864 \pm 170,56$ million per $\mathrm{ml}$ of sperm concentration. Macroscopic semen quality showed corresponding characteristics to most of bull semen quality in general. In the comparison of macroscopic characteristics of Javanese bulls which mostly have 3,6 $11,6 \mathrm{ml}$ in volume, with cream-colored semen, medium consistency, have spermin odor and semen concentration between $700-1.300 \times 10^{6} \mathrm{cell} / \mathrm{ml}$ [5]. Generally, a bull can produce fresh semen with $5-8 \mathrm{ml}$ of volume per ejaculation and concentration ranging from 800 to 2000 million per $\mathrm{ml}$ semen [6]. Differences in macroscopic quality for some bulls can be affected by the variation of ages. Research from Nyuwita et al. has shown that Simmental bulls with a group of ages ranging from 3 to 4 years old were able to produce more volume and concentration of semen compared to a group of bulls with 7 to 8 years old of age [7].

The microscopic evaluation of motility percentage has an average result of $73,01 \pm 1,78 \%$. This result of semen motility percentage is corresponding to semen motility standard for the bull. According to the Indonesian National Standard bull, fresh semen has to have a minimum of $70 \%$ of motility percentage in order to be processed as frozen semen [8]. Most of Simmental and limousin bulls have semen motility percentage ranging from 60 to $70 \%$. Simmental bull which is raised on tropical conditions usually has a low semen motility percentage [9]. Research from Muada et al. reported that bull semen motility collected in tropical climate areas has a lower percentage from the normal standard of fresh semen motility with an average of $58,80 \pm 14,35 \%$ [10].

\subsection{Post - Thawing Semen Motility}

Post-thawing motility standard according to Indonesian National Standard, has to be more than or equal to $40 \%$ in order to achieve a higher success rate of artificial insemination [8]. The observation result of semen postthawing motility shown in Table 2.
Table 2. Data tabulation of Simmental bull semen postthawing motility observation

\begin{tabular}{ccccc}
\hline \hline \multirow{2}{*}{$\begin{array}{c}\text { Days of semen } \\
\text { collection }\end{array}$} & \multicolumn{4}{c}{ Treatments } \\
\cline { 2 - 5 } & T0 & T1 & T2 & T3 \\
\hline & \multicolumn{4}{c}{-----------} \\
1 & 41,21 & 43,33 & 43,50 & 38,76 \\
2 & 40,33 & 45,50 & 43,67 & 41,47 \\
3 & 38,50 & 46,85 & 45,00 & 40,33 \\
4 & 41,50 & 41,67 & 43,50 & 40,71 \\
5 & 40,23 & 43,50 & 41,50 & 38,67 \\
6 & 48,33 & 49,50 & 51,23 & 45,50 \\
Mean & 41,68 & 45,06 & 44,73 & 40,91 \\
\hline
\end{tabular}

The result of semen evaluation on post-thawing motility showed that T0, T1, T2 dan T3 were not significantly affecting the percentage of motility $(\mathrm{P}<0,05)$. However, $\mathrm{T} 1$ and $\mathrm{T} 2$ with vitamin $\mathrm{E}$ addition on the level of $0,134 \mathrm{gram} / 100 \mathrm{ml}$ extender and 0,268 gram $/ 100 \mathrm{ml}$ extender showed a slight improvement in post-thawing motility percentage compared to T0 and T3. Vitamin E addition to the extender with a certain level would give a positive effect on the durability of semen to keep motility percentage stable until final processing for frozen semen production. Research from Lukman et al. reported that vitamin E addition to tris yolk extender with the dosage of $0,2-0,6$ for $100 \mathrm{ml}$ extender could give a significant increase in Bali bull sperm motility with the best result on the level of 0,4 gram/100 $\mathrm{ml}$ [11]. Vitamin $\mathrm{E}$ gave instant effect on motility because its nature which can easily dissolve on lipid from skim - yolk extender. 85). Vitamin E as an antioxidant has an essential role in giving protection to the membrane. Vitamin E could give a positive effect on the improvement of sperm motility, membrane integrity and membrane potential [2]. Vitamin E presence in semen extender has important role as a sperm antioxidant compound to prevent peroxidation reaction on the sperm membrane. Spermatozoa membrane mostly constructed from several chains of polyunsaturated fatty acids which were very vulnerable to free radicals reaction when exposed in free air. Zubair et al. reported that vitamin $\mathrm{E}$ as an antioxidant had proven capable of mitigating the effect of reaction with reactive oxygen species (ROS) dan lipid peroxidation (LPO) spermatozoa membrane so that semen quality will be preserved during the whole production process or cold storage [3, 12].

Reactive oxygen species (ROS) are some oxide compounds that can be produced by spermatozoa on aerobic conditions in the form of hydrogen peroxide $\left(\mathrm{H}_{2} \mathrm{O}_{2}\right)$, superoxide anion $\left(\mathrm{O}_{2}^{-}\right)$and radical hydroxyl $\left(\mathrm{OH}^{-}\right)$. These oxides are known for causing severe damage to spermatozoa as the result of lipid peroxidation of the plasma membrane with ROS. ROS formation on spermatozoa caused by chain reaction on membrane peroxidation with other oxides such as hydrogen peroxide and disruption of metabolism in spermatozoa cell. ROS was capable of inhibiting cell metabolism and the utilization of ATP from cell mitochondria [2, 13]. Less availability of ATP within the cell can reduce the 
progressive motility of sperm movement. Spermatozoa with damaged membrane from ROS reaction had lower post-thawing viability and motility compared to spermatozoa with full intact membrane [14].

Vitamin $\mathrm{E}$ is one of the molecules that can not be synthesized by spermatozoa. It has to be added separately on semen extender to provide the availability of antioxidants for spermatozoa. Vitamin E mechanism on inhibiting peroxidation is by breaking down the oxide chains of ROS and other free radicals thus its beneficiary capacity as antioxidant resulting in the improvement of sperm motility, viability and mitochondrial membrane functionality [15].

\subsection{Semen Mortality}

Mortality or death percentage of spermatozoa is the ratio between the number of mortal spermatozoa with the total number of spermatozoa observed. The observation result of semen mortality can be seen on Table 3 .

Table 3. Data tabulation of Simmental bull semen mortality percentage

\begin{tabular}{|c|c|c|c|c|}
\hline \multirow{2}{*}{$\begin{array}{c}\text { Days of } \\
\text { semen } \\
\text { collection }\end{array}$} & \multicolumn{4}{|c|}{ Treatments } \\
\hline & T0 & $\mathrm{T} 1$ & $\mathrm{~T} 2$ & $\mathrm{~T} 3$ \\
\hline & & & /0---- & ------ \\
\hline 1 & 8,50 & 7,62 & 10,32 & 12,50 \\
\hline 2 & 10,15 & 10,50 & 8,67 & 13,50 \\
\hline 3 & 12,33 & 4,50 & 5,67 & 18,21 \\
\hline 4 & 10,50 & 6,53 & 7,50 & 8,42 \\
\hline 5 & 14,50 & 9,23 & 12,50 & 17,20 \\
\hline 6 & 14,83 & 8,33 & 4,95 & 7,67 \\
\hline Mean & $11,80^{\mathrm{a}}$ & $7,79^{b}$ & $8,27^{\mathrm{b}}$ & $12,92^{\mathrm{a}}$ \\
\hline
\end{tabular}

The observation result showed that there was a significant effect of vitamin $\mathrm{E}$ addition to extender on mortality percentage $(\mathrm{P}>0,05)$. The lowest mortality percentage is shown on $\mathrm{T} 1$ and $\mathrm{T} 2$ with vitamin $\mathrm{E}$ addition on $0,134 \mathrm{gr} / 100 \mathrm{ml}$ extender dan 0,268 gr/100 $\mathrm{ml}$ extender. Sperm mortality generally caused by a damaged plasma membrane during the production process of frozen semen. The freezing process of semen usually gives a significant impact on plasma membrane breakdown which leads to increasement of mortality percentage. During the freezing process, the sperm membrane has to endure the damaging effects of lipid peroxidation and cold shock. Dropping temperature in the freezing process causing obstruction of phospholipid lateral movement and change of phase from liquid to gel, making the membrane to become more rigid and fragile in the process [3]. Vitamin E supplementation to semen extender could provide nutrition addition for spermatozoa in the form of antioxidants to protect the membrane from harmful reactions with free radicals. Vitamin E addition to the semen extender had proven to be beneficial to improve viability, concentration and preserving spermatozoa motility during cryopreservation in liquid nitrogen containers [16].
The high percentage of mortality on spermatozoa caused by a sudden change in osmotic pressure, within an extender solution. High extender solution concentration would instead cause severe damage on plasma membrane and disruption on permeability nature of cell membrane which leads to overcapacity of substances that has been absorbed by spermatozoa cell. Semen extender with over-osmotic pressure could cause simultaneous damage to the sperm membrane which would lead to an imminent decrease of motility and viability [17]. High osmotic pressure and concentration could also be caused from over dosage addition of vitamin $\mathrm{E}$ to semen extender. Vitamin $\mathrm{E}$ addition on very high dosage would become toxic and harmful for spermatozoa. Vitamin $\mathrm{E}$ addition on extender with increasing level would instead give negative impact on semen quality overall because over concentrated extender would affecting the osmotic pressure within cell which could lead to mebrane damage [17, 18]. Research from Lecewicz et al. also showed that on some certain levels of vitamin E addition, it would positively affecting on viability improvement and preserving spermatozoa motility at the standard percentage, however high level of vitamin E supplementation would instead become harmful and could cause significant drop on sperm motility percentage [18].

\subsection{Sperm Abnormality}

Sperm abnormality is a form of physical defect mostly on the spermatozoa cell body. A primary abnormality is a form of defection on the sperm cell head and acrosome cap, while secondary abnormality is a form of defection mostly on the tail part of the sperm cell $[2,19]$. This research focused mainly on secondary abnormality which was mostly occurred during frozen semen production. The observation result of sperm motility shown in Table 4.

Table 4. Data tabulation of Simmental bull semen abnormality percentage

\begin{tabular}{|c|c|c|c|c|}
\hline \multirow{2}{*}{$\begin{array}{c}\text { Days of } \\
\text { semen } \\
\text { collection }\end{array}$} & \multicolumn{4}{|c|}{ Treatments } \\
\hline & T0 & $\mathrm{T} 1$ & $\mathrm{~T} 2$ & T3 \\
\hline & \multicolumn{4}{|c|}{------------------------.\%"---------------------- } \\
\hline 1 & 10,33 & 5,23 & 4,67 & 6,33 \\
\hline 2 & 9,33 & 6,00 & 6,33 & 11.23 \\
\hline 3 & 6,00 & 5,33 & 5,50 & 8,33 \\
\hline 4 & 8,76 & 5,67 & 4,33 & 11,82 \\
\hline 5 & 9,37 & 5,67 & 5,33 & 11,47 \\
\hline 6 & 7,50 & 5,00 & 4,57 & 8,33 \\
\hline Mean & $8,55^{\mathrm{a}}$ & $5,48^{\mathrm{b}}$ & $5,12^{\mathrm{b}}$ & $9,59^{\mathrm{a}}$ \\
\hline
\end{tabular}

Observation result showed highly significant effect of vitamin $\mathrm{E}$ addition on sperm abnormality percentage $(\mathrm{P}<0,01)$. The lowest abnormality percentage presence on $\mathrm{T} 1$ and $\mathrm{T} 2$ with the vitamin $\mathrm{E}$ addition of 0,134 gram $/ 100 \mathrm{ml}$ extender and $0,268 \mathrm{gram} / 100 \mathrm{ml}$ exxtender. These results of abnormality percentage of sperm on $\mathrm{T} 1$ dan T2 were also still on the range of normal standard of 
sperm abnormality percentage. Sperm abnormality percentage must be less than $10 \%$ in orfer to get a moderate quality of frozen semen [19]. Vitamin E addition with too much low or high level would instead increase sperm abnormality percentage above normal standard. Research from Daramola et al. showed that frozen semen with vitamin $\mathrm{E}$ addition on precise level would give a significant results on the decrease of sperm abnormality percentage, however on the higher dosage abnormality percentage would increase gradually along with the dosage increasement [20].

Sperm abnormality can be categorized as primary or secondary abnormality both have different causes. Primary abnormality occurred on the spermatogenesis process inside testis because the maturation process of sperm did not function properly, while secondary abnormality often occurred after sperm cells leaving tubulous seminiferous or outside main reproductive organs [21]. Sperm abnormality on frozen semen generally classified as a secondary abnormality which was caused by few defections on several parts of the sperm cell body especially on sperm tail. During the semen freezing process, spermatozoa had to sustain some chemical reactions with oxygen and nitrogen, disparity of osmotic pressure and temperature changes which could give damaging impact into sperm cells [22].

Abnormality mostly caused by various treatments and mechanical process during frozen semen production can be minimalized by adding vitamin $\mathrm{E}$ to semen extender as antioxidant supplementation. Vitamin E supplementation in semen extender would provide protection to cell membrane from free radicals so that it would also reduce the possibilty of damages that could lead to sperm cell abnormality and mortality [23]. Semen freezing process contributed the most on sperm celldamaging impact as the result of oxidation reaction with free oxygen and liquid nitrogen. Drastic temperature changes also caused cold shock on spermatozoa which could lessen the rigidity and permeability of the plasma membrane. Zhao et al. reported that vitamin $\mathrm{E}$ addition on frozen semen extender could escalate enzymatic activity within sperm cell metabolism, strengthen the inner layers of the sperm cell membrane and mitigate the possibility of oxidation reaction during semen freezing process [16].

\section{CONCLUSION}

Vitamin E addition to Simmental bull semen extender with the level of 0,134 gram / $100 \mathrm{ml}$ extender gave the best result on the improvement of post-thawing quality included motility, mortality and abnormality percentage.

\section{ACKNOWLEDGMENTS}

The author would like to thank all the officials and staff members of Ungaran Artificial Insemination Center and other related parties that have helped us to finish this research accordingly.

\section{REFERENCES}

1. E. Diany, Suryahadi, T. Muhandri. Marketing strategy of bull frozen semen distribution in BIB Lembang. J. Manajemen IKM. 11(1), $62-71$. (2016)

2. M. R. Ugur, A. S. Abdelrahman, H. C. Evans, A. A. Gilmore, M. Hitit, R. I. Arifiantini, B. Purwantara, A. Kaya, E. Memili. Advances in cryopreservation of bull sperm. Front. Vet. Sci. 6(268), 1 - 15. (2019)

3. M. Hussain, S. S. Begum, M. K. Kalita, K. U. Ahmed, R. Nath. Additives used in semen preservation in animals. Intl. J. Chem. Studies. 6(5), 354 - 361. (2018)

4. Feradis. Antioxidant role on semen freezing process. J. Peternakan. 6(2), 63 - 70. (2009)

5. L. N. Varasofiari, E. T. Setiatin, Sutopo. Evaluation of fresh semen quality of Java cattle based on storage duration. J. Anim. Agric. 2(1), $201-208$. (2013)

6. J. L. Schenk. Review: Principles of maximizing bull semen production at genetic centers. Intl. J. Anim. Biosci. 12(1), 142 - 147. (2018)

7. A. Nyuwita, T. Susilawati, N. Isnaini. Semen quality and frozen semen production of Simmental bull on different ages. J. Ternak Tropika. 16(1), 61 - 68. (2015)

8. Indonesian National Standard. Bull Frozen Semen. SNI 4869-1-2017. National Standard Agency, Jakarta. (2017)

9. S. Lestari, D. M. Saleh, Maidaswar. Limousin bull semen quality profil with variaton of ages in Lembang Artificial Insemination Center West Java. J. Ilmiah Peternakan. 1(3), 1165 - 1172. (2013)

10. D. B. Muada, U. Paputungan, M. J. Hendrik, S. H. Turangan. Limousin and Simmental bull semen characteristics in Lembang Artificial Insemination Center. J. Zootek. 37(2), 360 - 369. (2017)

11. H. Y. Lukman, W. Busono, S. Wahyuningsih, S. Suyadi. Sperm motility and viability after $\alpha$ tocopherol dilution in tris aminomethane-base extender during cold storage in bali bull. International J. Chem. Tech. Res. 6(14), 5726 5732. (2014)

12. M. Zubair and M. Ali. Effect of selenium and vitamin $\mathrm{E}$ on cryopreservation of semen and reproductive performance of animals (a review). $J$. Ento. Zool. Studies. 3(1), 82 - 86. (2015)

13. M. Hezavehei, M. Sharafi, H. M. Kouchesfahani, R. Henkel, A. Agarwal, V. Esmaeili, A. Shahverdi. Sperm cryopreservation: a review on current molecular cryobiology and advanced approaches. Repro. Bio. Med. Online. 37(3), 327 - 339. (2018)

14. A. Kumaresan, A. Johannisson, E. M. Al-Essawe, J. M. Morrell. Sperm viability, reactive oxygen species, and DNA fragmentation index combined 
can discriminate between above- and belowaverage fertility bulls. J. Dairy Sci. 100(7), 5824 5836. (2017)

15. M. Motemani, M. Chamani, M. Sharafi, R. Masoudi. Alpha-tocopherol improves frozenthawed sperm quality by reducing hydrogen peroxide during cryopreservation of bull semen. Spanish J. Agric. Res. 15(1), 1 - 7. (2017)

16. X. L. Zhao, Y. K. Li, S. J. Cao, J. H. Hu, W. H. Wang, R. J. Hao, L. S. Gui, L. S. Zan. Protective effects of ascorbic acid and vitamin $\mathrm{E}$ on antioxidant enzyme activity of freeze - thawed semen of qinchuan bulls. Gen. Mol. Res. 14(1), 2572 - 2581. (2015)

17. O. I. Azawi and E. K. Hussein. Effect of vitamins c or e supplementation to tris diluent on the semen quality of awassi rams preserved at $5{ }^{\circ} \mathrm{C}$. Vet. Res. Forum. 4(3), 157 - 160. (2013)

18. M. Lecewicz, R. Strzeżek, W. Kordan, A. Majewska. Effect of extender supplementation with low - molecular - weight antioxidants on selected quality parameters of cryopreserved canine spermatozoa. J. Vet. Res. 62(1), 221 - 227. (2018)

19. W. A. Khalil, M. A. El-Harairy, A. E. B. Zeidan, M. A. E. Hassan, O. M. Elsaeed. Evaluation of bull spermatozoa during and after cryopreservation: structural and ultrastructural insights. Intl. J. Vet. Sci. Med. 6, 49 - 56. (2018)

20. J. O. Daramola, E. O. Adekunle, O. E. Oke, O. Ogundele, E. A. Saanu, A. J. Odeyemi. Effect of vitamin $\mathrm{E}$ on sperm and oxidative stress parameters of west african dwarf goat bucks. Tropic. Sub. Agroeco. 19, 151 - 158. (2016)
21. S. Ahmed, M. I. R. Khan, M. Ahmad, S. Iqbal. Effect of age on lipid peroxidation of fresh and frozen-thawed semen of Nili-Ravi buffalo bulls. Ita. J. Anim. Sci. 17(3), 730 - 735. (2018)

22. P. K. Mittal, M. Anand, A. K. Madan, S. Yadav, J. Kumar. Antioxidative capacity of vitamin E, vitamin $\mathrm{C}$ and their combination in cryopreserved bhadavari bull semen. Vet. World. 7(18), 11271131. (2014)

23. H. A. Pour, A. M. Tahmasbi, A. A. Naserain. The influence of vitamin $\mathrm{E}$ on semen characteristics of ghezel rams in during cooling and frozen process. Euro. J. Zool. Res. 2(5), 94 - 99. (2013) 